Zealand 44 (14 to Pakistan, 10 to Ceylon) and India 14 (10 to Ceylon, 4 to Indonesia). Posts of professors at universities and technical institutes remain hard to fill, and recruitment of some types of engineers and technicians is difficult. More inquiries are being made about the availability of firms of consultants. As regards equipment, the trend is towards equipment for establishing or expanding training and research facilities in the region with the object of training instructors. Equipment has already been supplied, ordered or offered to the value of $£ 1.5$ million against requests for more than $£ 2$ million, including $£ 344,000$ worth of laboratory equipment for research, $£ 927,000$ of training equipment and $£ 97,000$ of equipment for food and agriculture, most of this coming from Great Britain.

The movement to create or expand and improve training centres in South and South-East Asia continued. Among many examples given in the report are the assignment by Great Britain of four medical scientists to help the new medical colleges established by the Government of India by lecturing and demonstrating for ten weeks in India new techniques in diagnosis and treatment; the library facilities given by Australia and New Zealand to the University of Malaya, Singapore; the supply to Pakistan by Britain of equipment, an engineer and three demonstrator instructors to assist the change-over from manual control to automatic telecommunications; and the training of twenty-two teachers to help organize and administer technical high schools being established by the Pakistan Government.

Mutual aid in the region also made some further progress, and greater use continues to be made of technical assistance to promote economic development and raise the standard of living. Among new projects in this field the emphasis has now shifted from measures to avoid loss from pests, weeds and disease to measures to preserve food. Australia is giving equipment to the Dairy Research Institute, Bangalore, and is also arranging a tour for milk commissioners from Bombay and West Bengal and the head of the Dairy Technology Division of the Indian Dairy Research Institute to observe the largescale handling and manufacture of milk and milk products. The Ceylon Government is taking steps to establish a rice research organization to help the drive towards self-sufficiency in rice, and Japan is sending two leading rice physiologists to study conditions in the main rice-growing areas and submit a detailed scheme for the proposed research organiza. tion. Britain has assigned an expert to the Indian Central Cotton Committee to review cotton research at the Institute of Plant Industry, Indore, and is supplying equipment to the newly established Pakistani Institute of Cotton Research and Technology at Karachi. Under the Colombo Plan agriculture is being promoted, along with industry, by irrigation and power projects, while output is being increased by the improvement of transport and communications. Britain, for example, is training the assistant director of soils for the Central Road Research Institute, Delhi, and has sent the Deputy Chief Engineer of the B.B.C. to review installation work already carried out by Radio Pakistan and to advise on the technical aspects of the future development plans; it has also assisted the Indian Central Glass and Ceramic Institute and the Central Leather Research Institute with technical facilities. Australia is providing research equipment for the brick and tile industry of Ceylon and is training a Pakistani officer who is to be employed on wool research testing, as well as five sugar technologists for Pakistan's new sugar factories.

While more trainees were sent abroad under the Scheme in 1954-55 than in any previous year, the training was also more closely fitted to the needs of the development projects. Under the Colombo Plan, including United States assistance, the countries of the area have now sent abroad 5,701 trainees and received 1,341 experts, mostly from outside the region; with the United Nations figures, the totals are 7,159 trainees and 3,741 experts. A large measure of co-operation has now been achieved, and the co-oporating governments have a better idea of what forms of assistance the respective agencies can best provide.

\section{MAN-POWER IN THE BRITISH COAL INDUSTRY}

TN a lecture to the Royal Institution of Public 1 Administration on November 28, 1955, Mr. A. H. A. Wynn, scientific member of the National Coal Board, discussed the momentum of decline of the coal industry, which continued in spite of any increase in demand. Behind a fall in production from 287 million tons in 1913 to 174 million tons in 1945, the industry's ability to produce has also fallen. Mr. Wynn did not discuss many of the factors contributing to this momentum of decline, but pointed out that because of the gradual exhaustion of reserves in each individual mine, the productive capacity of the coal industry must decline by two or three per cent each year, if there is no large-scale reconstruction and no new collieries are opened. This decline affects adversely the standards of the industry's technology, its staff structure, its world reputation and its ability to recruit staff. Mr. Wynn did not discuss these imponderable psychological and educational problems, however, but rather the creation and growth of special administrative structures, some of which would be the responsibility of scientists and engineers. These organizations, he thought, are the most hopeful means of reversing the decline. He suggested that they fall under four headings : exploration, or the survey of natural resources; capital investment; the improvement of methods of production, primarily by promoting technological progress; and research and development, directed to increasing the commercial value of the industry's products. All are closely related; but only the first is peculiar to an extractive industry, and the inadequacy of our knowledge of coal resources is a factor in the momentum of decline that has delayed the reconstruction of the industry. The Board has also had to establish from slender resources the Planning Branch of the Production Department responsible for the large-scale reconstruction of old mines and the development of new ones, and its task has been made more difficult by the scarcity of suitable staff and the urgent demands for more coal.

Before 1947, the resources of the industry of Britain for promoting technological development were few ; but the industry was profoundly dependent on heavy labour. A Mechanization Branch of the Production Department was established in 1947, supported by an Engineering Branch, and recently the Board has established a Central Engineering Establishment, near Burton-upon-Trent, for pursuing 
the development of new machines and providing guidance to manufacturers; and a Mining Research Establishment was set up at Isleworth in 1952. The Safety in Mines Research Establishment of the Ministry of Fuel and Power is still the largest mining research establishment in Britain, and the National Coal Board has inherited very few men experienced. in mining research. In the post-war man-power situation, the Board has found difficulty in recruiting the scientific and technical staff it needs, and this is the main limit on the Board's expansion plans. Mr. Wynn emphasized that production depends on the outcome of a race between increased mechanization and falling man-power in the mines. Two other organizations, however, have also been established which can do much to improve productivity. The Scientific Department has established a Field Investigation Group, analogous to the operational research teams of the Service departments, and the Production Department has set up a Method Study Branch. These establishments are in close touch and will play a big part in reducing man-power requirements.

\section{SOCIAL PROBLEMS OF INDUSTRIAL DEMOCRACY}

$\mathrm{T}$ HE Department of Social Science, University of Liverpool, has published, as Occasional Papers No. 2, "Industrial Democracy : a Revaluation", by W. H. Scott (pp. 40. Liverpool : University Press, 1955 ; 3s. 6d.). This essay is intended to meet the needs of industrialists, trade unionists and others who wish to acquaint themselves rapidly with some of the broad conclusions resulting from systematic research and current thought on this topic. It is limited, however, primarily to problems arising at the factory- or plant-level and is essentially a stocktaking. Industrial democracy is regarded as implying the participation, to a greater or lesser extent, of those who work in industry in determining the conditions of their working lives. The review answers the question, "Is industrial democracy desirable?" with an emphatic affirmative, and Mr. Scott also believes that industrial development has justified our faith in the efficacy of democracy to check the arbitrary use of power.

While an extension of the democratic principle at the formal policy-making level of a firm is important, its application in day-to-day executive leadership is equally vital, and these two processes are interdependent. Mr. Scott makes some constructive comments here, and on the position of the trade unions, which are of especial interest at the moment. $\mathrm{He}$ notes the need to develop "consultative leadership" as part of the administrative routines of a firm at every level, as an essential concomitant to more effective formal procedures at the policymaking levol, pointing out that higher management must take and maintain the initiative in both these respects. He also directs attention to the presupposed attitudes of leadership and administrative ability and to the implications in respect of selection and training for such posts. Similar considerations apply to the trade unions, and if the excessively bureaucratic tendencies of some unions are to be checked, and a balance achieved between the need for a measure of centralized administration and the desirability of developing local initiative and responsibility, then similar criteria must be applied to the selection and training of full-time trade-union officials.

Just as the effective working of any new procedures within the firm calls for a capacity for consultative leadership on the part of managers, so the delegation of greater responsibility to lay-representatives by the unions, which is so essential to industrial democracy, requires appropriate attitudes on the part of officials if it is to be used creatively. Moreover, industry does not exist in vacuo, and Mr. Scott points out that to achieve stable and enduring changes in industry, we must also concern ourselves with developments in other institutions of our society and particularly those which are basic and most formative of personality.

\section{FIBRE MICROSCOPY}

A WELL-ATTENDED symposium and exhibition organized by the Industrial Section of the Royal Microscopical Society was held at the British Pharmaceutical Society in London on November 16, three sessions of papers being given in the lecture theatre, while an exhibition was staged in the hall. Opening the first session of papers, Dr. R. C. Faust discussed the use of the interference microscope in the examination of fibres. The degree of molecular orientation and closeness of molecular packing at different regions of an anisotropic fibre have been studied by means of multiple-beam interference with the conventional microscope and by means of twobeam interference with the Baker interference micro. scope. Mr. D. S. Gowers then described the study, by interferometric methods, of the adhesion between fibres. When an artificial point of contact between a fibre and a quartz plate is examined by incident illumination, Fizeau fringes give a contour map of the fibre surface. The area of contact can be determined by the intensity distribution across the central dark spot. The effect of humidity, temperature and contaminants in the fibre was discussed.

The first two papers in the second session were devoted to the methods of producing replicas for use in the electron microscope. With textile fibres it is the surface that is of main interest, and this may be studied by means of replicas of the fibres, examined under the reflexion electron microscope. The curvature of the fibre presents an added difficulty in obtaining a successful replica, and Dr. J. Dlugosz described the various methods of replication investigated to obtain a successful routine method.

A method of producing solid metal replicas of fibres, for use in the reflexion electron microscope, was then described by D. E. Bradley, who discussed the advantages of this method over that of direct examination, and Dr. K. Little considered the use of the electron microscope in conjunction with other techniques, such as X-ray diffraction, histology and chemical investigations, in the study of fibres in human connective tissues. Each mothod of microscopy has its advantages and its limitations. H. W. Emerton's paper, read by D. H. Page, described how, by using three methods-namely, light microscopy, reflexion electron microscopy and transmission electron microscopy-in the study of natural fibres, a more complete picture can be obtained. By means of a plastic metal replica, the same fibre can be examined by all three methods.

The third session was opened by Dr. A. E. J. Vickers with a short historical survey of the pro. 